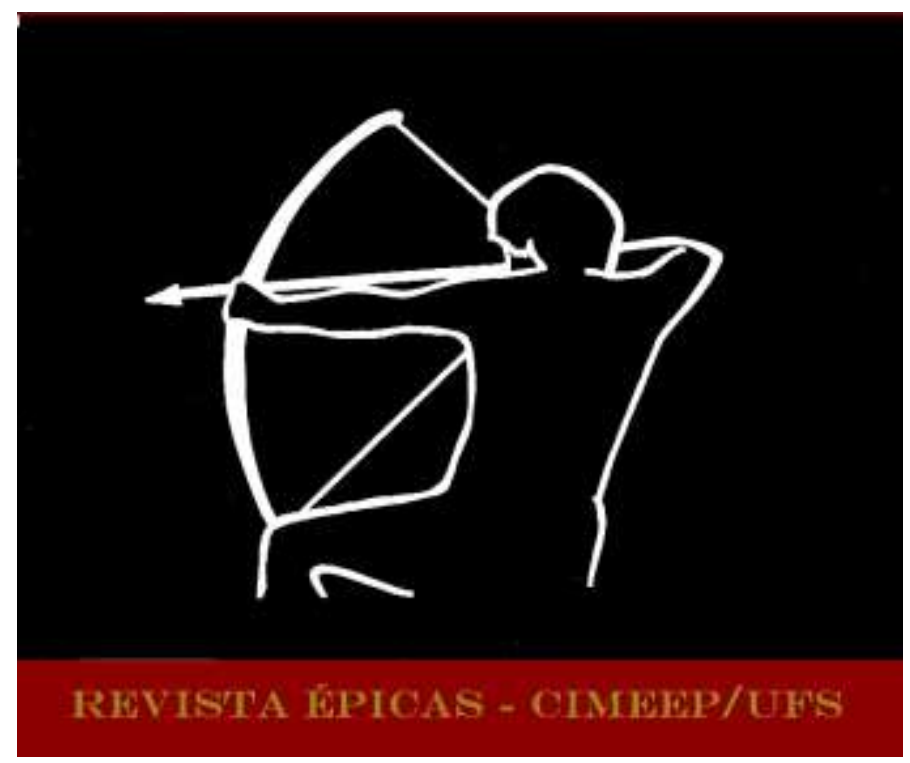

BARBOSA, Manuela Ribeiro. Aníbal Machado, homeopoeta. In: Revista Épicas. Ano 4, N. 7, Jun 2020, p. 1-23. ISSN 2527-080-X.

\title{
ANÍBAL MACHADO, HOMEOPOETA
}

RESUMO: Propomos que Aníbal Machado, em Cadernos de João, explora elementos como a sabedoria, a oralidade, o ritmo, mas também a escrita cuidada e a experiência concreta para compor obra híbrida entre poesia e prosa. Autor de produção relativamente pequena, quase circunscrita a formas breves, ele recupera, em miniatura, o sentido da narração, na medida em que nunca deixa de parte a vida. ${ }^{1}$

Palavras-chave: Aníbal Machado; hibridismo; poesia; prosa.

ABSTRACT: Aníbal Machado, in Cadernos de João, explores elements such as wisdom, orality, rhythm, but also elaborated and concise writing and concrete experiences, in order to compose a work between poetry and prose. Author of a relatively small production, almost limited to brief genres, he rescues, through his miniatures, the true meaning of narration, because life is never absent from the text.

Keywords: Aníbal Machado; hybridity; poetry; prose.

\section{Introdução}

A produção do sabarense Aníbal Monteiro Machado (1894-1964) não é extensa, embora tampouco exígua. Consiste em alguns contos, a novela Vila Feliz, que compõem Histórias Reunidas, depois somadas a um conto inédito e republicadas em A morte da porta-estandarte e outras histórias, um volume de textos dispersos (poemas, poemas em prosa, ensaios e aforismos), Cadernos de João e o romance João Ternura. Há ainda cometimentos interessantes, de escasso registro, como escritos da juventude, ${ }^{2}$ cujo valor é quase exclusivamente documental, traduções não publicadas e obras coletivas. O mineiro não foi um literato de

\footnotetext{
${ }^{1}$ Este trabalho aproveita, reformulando-os severamente, trechos da tese de doutorado K. no Brasil: Kafka, Murilo Rubião e Aníbal Machado, apresentada ao Programa de Pós-Graduação em Letras: Estudos Literários da Faculdade de Letras da Universidade Federal de Minas Gerais (UFMG) em julho de 2014, sob a orientação do Prof. Dr. Elcio Loureiro Cornelsen.

2 Para um vislumbre da obra inicial do autor, ver "Sob a máscara de Antônio Verde: um estudo do universo literário de Aníbal Machado no início do século XX", de Marcos Vinícius Teixeira.
} 
gabinete, não teve pressa para se ver em letra impressa, e podemos crê-lo quando afirmou: "Prefiro antes conversar do que escrever; antes ouvir que ler." (MACHADO apud ANTELO, 1994, pág. 41-42)

O legado como incentivador, colaborador e propulsor de outros artistas, por outro lado, imensurável pela característica desse tipo de influência, sobressai, amiúde, nos testemunhos coetâneos. ${ }^{3}$ Para Raúl Antelo, “Aníbal representa para o Rio de Janeiro (...) aquilo que Mário de Andrade significou para a São Paulo dos 30 e 40: um arregimentador: animador cultural, introdutor das vanguardas poéticas, intelectual empenhado e partidário" (ANTELO, 1994, pág. 15).

A contaminação da imagem pelo favor dos contemporâneos tende a nublar sua valoração isenta, mas o justo julgamento não parece ter seduzido o escritor. Ele mesmo, no livro que elegemos para esta releitura, Cadernos de João (1957), formula um conselho a quem com isso se apoquente: "Se foi esquecida a obra a que deste ou supões ter dado o melhor de teu gênio e de teu sangue, não fiques ao lado dela como guardião do túmulo, mas como lavrador à espera de que a semente germine." (MACHADO, 2002, pág. 46)4

Amiúde o escritor vai contrapor vida e obra. Em geral, porém, ele dará a palma da vitória à primeira, mesmo que o faça dando a mão à palmatória, isto é, escrevendo. Confissão de derrota e da futilidade da tarefa que ele exerce conscienciosa, ambivalentemente, afinal, "[m]esmo a caminho da forca se deve apreciar o passeio" (MACHADO, 2002, pág. 65).

$\mathrm{O}$ traço afirmativo da pena anibalina tem melancolia, mas benévola e bem-humorada. É o que os críticos vão formular de diferentes modos. Mario Pontes frisa não se tratar de escritor amargo, senão de alguém que "se apresentava como uma personificação do bom humor e da amizade, essa virtude cada vez mais ausente da sociedade contemporânea" (PONTES, 2004, pág. 12), enquanto Cavalcanti Proença enfatiza que não falta a essa sensibilidade certa ironia atenuada, já que, “[p]ara cultivá-la, chega a dominar o orgulho, a substituir a ira incivilizada por um sorriso ameno, a aceitar a imperfeição humana, transformando-a em divertimento perene." (PROENÇA, 1974, pág. xxiv).

\footnotetext{
${ }^{3}$ A título de ilustração, cf. o depoimento dos amigos Pedro Nava, Paulo Mendes Campos, Carlos Drummond de Andrade e Aires da Mata Machado Filho: "Tinha uma grande doçura no olhar aumentada ainda pela vaguidão de míope. Às vezes como que fenda num vidro e a expressão mudava quando ele tinha de exercer a sua argúcia. Era duma bondade máscula e profunda, um amigo exemplar, companheiro inigualável e exato, homem de honra e de conviç̧ões inabaláveis." (NAVA, 2003, pág. 93); "Todo mundo era amigo de Aníbal Machado: os poetas todos: os anteriores a 22, os integrantes da Semana de Arte Moderna, a geração de 45, os concretistas (...) todos procuravam Aníbal Machado. Era um consertador de material humano e era também um homem que aceitava material humano tal como ele é, precário e torto. (...) Era um homem tocado pela graça da compaixão e virilmente bandeado para o partido da vida." (CAMPOS, 1984, pág. 3); "Assim muitos ajudou a viver, e a não sei quantos salvou de si mesmos, do tédio, da solidão e da secura, pois ele todo era uma casa, de mesa posta e luz acesa, para o desesperado e o bêbado, a provar que a cidade não é labirinto do inferno, se nela florescem o domingo feérico dentro do domingo, a paciência e o sorriso. (...) Eis que, chegada a hora, a morte foi uma visita entre outras, a o homem que recebia duzentas mil visitas, inclusive as cacetes, e não era presidente de nada." (ANDRADE, 1975 , pág. 4); “... a casa em que morava passou a ter portas abertas para todos aqueles que amavam as artes, da arquitetura à literatura; sabiam fruir o dom gratuito da vida, da ociosidade dourada ao anseio de compreender, da boêmia pura e simples ao gosto de sonhar. Esparzindo eflúvios de ternura, a todos congregava, na atmosfera preferida. Tudo sem horários, nem outras restrições temporais ou espaciais. Ninguém ainda se pareceu com ele." (MACHADO FILHO, 1984, pág. 1)

${ }^{4}$ Esse posicionamento condiz com a aversão do escritor - que é fruto do amadurecimento, a julgar pela verbosidade e artificialidade de sua obra de juventude - ao uso da literatura como meio de ascensão social e manobras de exibicionismo. Segundo a filha Maria Clara, idealizadora do teatro-escola Tablado, ele era "o antivida literária": paciente até com os chatos, detestava que literatos perturbassem suas famosas domingadas, nas quais reinava a informalidade e a desordenada anarquia das conversas sobre tudo, música e dança; zombava da Academia Brasileira de Letras, não gostava de enfrentar a crítica e não apreciava lançamentos e noites de autógrafos (MACHADO, 1994, pág. 14).
} 
Elza Miné igualmente refere a "pincelada irônica", não sem antes declarar o recorte lírico de Aníbal "[t]ransbordante de compreensão" (MINÉ, 1984, pág. 11), o que Antônio Olinto secunda. ${ }^{5}$ Otto Maria Carpeaux, depois de um retrato cativante - ainda mais recordarmos tratar-se de alguém fisicamente pouco imponente - crava que nele não se encontrava "[n]ada daquela taciturnidade grave, soturna, lacônica que desde Saint-Hilaire se atribui aos mineiros." (CARPEAUX, 1984, pág. 2) Donde se conclui que Aníbal Machado era carioca típico... 6

Essas virtudes litorâneas, ${ }^{7}$ distantes do estereótipo de fechamento e insinceridade, dir-se-ia, em diagnóstico afoito, decorrerem da confusão da obra com o homem. Mas não seria uma conclusão acurada, pois tais atributos se depreendem igualmente dos mundos poéticos e mesmo da crítica que o escritor constrói. O que haverá entre bio e graphía? Basta-nos admitir que, nos mais bem realizados artistas, subsiste uma identidade entre vida e obra semelhante à de corpo e sombra. Não se obtém adesão total de uma à outra, esta poderá eventualmente ser menor, maior, mais ou menos conforme àquela, mas jamais uma existiria sem a outra, a menos que não houvesse luz. Nessa metáfora não muito bem construída, a luz pode ser interpretada como a inspiração criadora, iniciada pelo poeta e vivificada pelo fruidor. Sem ela, há apenas ou corpo - a existência do artista - ou sombras (obras mortas em seu abandono - seja a obscuridade ou ausência de leitores ou cultores).

A permanência temporal de uma criação artística após a morte do agente responsável por sua existência material é consequência da operação de transpor para o papel inanimado, por meio do elemento simbólico e da habilidade formal, parte da experiência humana, um sopro vital, que se permita comunicar a outros. A cada nova leitura a obra se transforma, e o homem, ainda que de forma fantasmática, sobrevive.

\footnotetext{
5 “E Aníbal Machado mantém, diante dos desastres, o mesmo sorriso de compreensão. Há um lanho de tragédia grega na insistência com que o escritor descreve cenas assim, mas o poeta lírico, que não deixa de existir em Cadernos de João, parece pedir desculpas pelo mundo e sugerir que deve haver, em tudo, uma explicação, um sentido, uma finalidade. Um dia, chegaremos a compreender. A linguagem de Aníbal Machado é, por isso, sumamente otimista. Como a de um humorista amargo, que sentisse, apesar do lotação esmagado, a pureza da paisagem." (OLINTO, 1959, pág. 19)

${ }^{6}$ A mitologia do mineiro foi examinada por Aníbal. No "Esboço de Retrato" que estampa o trigésimo quarto número da revista Leitura, em 1949, o prosador descreve: "Reservado por temperamento, o mineiro prefere escutar. E escuta como ninguém, com vontade de comunicar-se e falar também. Ante os exagerados, os que gesticulam muito e discutem alto - retrai-se timidamente, mas no íntimo os admira e aprecia como se desejasse também ser assim. Passados os primeiros momentos, mergulha no seu mutismo, achando graça de se ter deixado fascinar: a reflexão infiltra-se em seu entusiasmo. Voltando os mesmos estímulos, já o mineiro reage agora em tom menor, nunca esquecido da ingenuidade e boa-fé com que se conduzira a primeira vez. Alarga, assim, o intervalo entre a ação e a reação." (MACHADO, 1994, pág. 43)

7 Myriam Lay Brander, destacando a importância da resistência característica da literatura pós-colonial e do elemento natural, em particular do mar em Cadernos de João, propõe que Aníbal abraça, na obra, uma poética do arquipélago, devedora dos surrealistas franceses e de Edouard Glissant, reunindo "una gama de géneros cortos que se presentan en un conjunto fragmentario: reflexiones (filosóficas), máximas, microrrelatos, diálogos, descripciones poéticas, retratos de personajes, lecciones para la vida. (...) De igual manera, los aforismos de Machado, aunque son fragmentos aislados que se pueden leer y entender en forma autónoma, se organizan en archipiélagos cuyas islas se relacionan por lazos temáticos, semánticos, formales y gráficos." (BRANDER, 2015, pág. 138) Embora ofereça intuições bastante úteis, o artigo acaba se distanciando de nossas convicções a respeito de Aníbal, defendendo que sua criação se fundamenta na lógica do arquipélago, nos níveis temático e semântico, formal e gráfico, sustentando ainda que o próprio gênero aforístico se caracteriza pela arquipelização. Para nós, a existência de agrupamentos menores dentro do livro não é fruto de cálculo e de uma visão de conjunto, mas justamente da percepção da irredutibilidade dos elementos a um todo coeso. A começar pelo título, Cadernos de João remete para fora de si, explicitando uma referência - João Ternura - sobre a qual a coletânea há de se impor, porque sua linguagem se aproxima da vanguarda e do pensamento de nossa época. No inacabamento, na diversidade, na colagem, nas ligações tênues que se estabelecem e se rearticulam livremente, a força da obra é menos a do arquipélago do que a do naufrágio que aporta à praia...
} 


\section{Gênero, número e grau}

Qual seria a obra imorredoura de Aníbal Machado? A redação de João Ternura se estendeu por quase quarenta anos, do começo ainda na primeira fase do Modernismo (TEIXEIRA, 2005, pág. 93) à apressada conclusão no leito de morte do escritor. Não somente em nossa visão, contudo, mas na de estudiosos e especialistas ${ }^{8}$ e quiçá em parte na do próprio Aníbal, ${ }^{9}$ o romance fracassa.

Porém talvez não devamos enveredar por um raciocínio que o escritor mesmo recusou: celebridade, posteridade, legado, tudo é tratado como perda de tempo nos Cadernos de João. É o que lemos numa fantasia sem título sobre a "projeção desproporcionada" (MACHADO, 2002, pág. 54), em que o eu se solidariza com "o prejudicado e o invejoso" feridos pelo louvor indevido que ele, poeta, recebe e menospreza ("nada disso vale nada").

Mais extensamente e logo a seguir, a polêmica retorna em "A procura", que poderia ser caracterizado, utilizando-se a terminologia de Francilene Cechinel, como um miniconto. Graças ao formato enxuto, podemos citar a íntegra, que dá a noção da confusão entre exterioridade e interioridade; do perigo do charlatanismo, apelo contra o qual é preciso reagir valentemente; da autoironia, do exasperante quiproquó e do hilariante (porque sério) mal-entendido na caçada ao infeliz que não sabe o que mais oferecer para que the seja dado permanecer em sua aurea mediocritas. 0 texto se desenrola até soar como se o protagonista se metamorfoseasse de santo em animal raro ou mesmo em utensílio, que a turba vai acabar destruindo para saber o que lá vai dentro dele:

Há alguém ou qualquer coisa em mim vista pelos outros e que não chego a perceber.

Sobretudo, quando me festejam. Às vezes me fazem maior. E isso me tira o equilibrio. Outras vezes, sou totalmente inventado sem que o saiba.

Saio então à minha procura.

Como não encontro nada, corro a mostrar o equívoco. Dou as razões. Exponho a minha fraqueza, o meu vazio.

Mas ninguém aceita a desculpa: alegam todos que é por humildade, que a humildade não faz senão me tornar maior. Aí, o equívoco é ainda mais grave. Começam a ver auréola em mim. Os quiromantes pedem-me a linha do sol, os astrólogos a hora e a data do nascimento.

Que fazer? Não me deixam em paz!

Desde manhã já acordo com horror de ser o que eles pensam.

Se, devido à evidência dos meus despojamentos, consigo por algum tempo por algum tempo o estado de coisa nula, de criatura apagada e esquecida - não dura muito o bem-estar: vão logo buscar-me ao meu buraco.

E quanto mais desminto, maior a romaria.

Querem alivio, querem a fórmula, querem a verdade!

Até as mulheres encostam a boca aos meus ouvidos para confessar desgraças. Pedem-me consolo, eu também peço, nós nos abraçamos, mas os outros se aproximam, e acham que não é decente. Não se pode nem sair nesta cidade. Os aflitos avançam, os indigentes estendem as mãos. Volto a esconder-me no meu antigo buraco. Mas logo uma fila enorme se forma à entrada. Ultimamente tem sido uma verdadeira romaria.

\footnotetext{
${ }^{8} \mathrm{Cf}$. Weisz e Teixeira, nas referências.

${ }^{9} \mathrm{Na}$ introdução ao volume, o mineiro afirma: "É possível que alguns leitores, de tanto ouvirem falar neste livro, o recebam de pedras na mão. Especialmente os da geração mais antiga. Tal seria a minha reação se, em vez do autor, fosse eu aqui o leitor. A publicidade involuntária que o livro recebeu antes de terminado deixou atemorizado o autor. Gostaria este que a obra cumprisse naturalmente o seu destino, sem forçar o sentido que acaso venha a assumir em cada leitor e em cada geração literária. Quanto mais se fazia por ocultá-la (e eram ainda peças retiradas a um corpo apenas pressentido e parcialmente descoberto, mais ela ganhava existência mítica da qual, por isso mesmo, o autor se sentia desligado." (MACHADO, 2004, pág. 23)
} 
Inútil a placa com os dizeres: "Saí. Eu também procuro". Inútil.

Ninguém se persuade, a fila nem se move.

Às vezes me arrancam lá do fundo. Agarram-me, percutem-me, viram-me para os lados, obrigandome a arregalar os olhos, a dizer alguma coisa, a pronunciar huhmplfst. Eu pronuncio huhmplfst, $e$ eles se exaltam ainda mais, dão urros, tiram-me pedaços de roupa, como se eu fora um monstro, um santo.

E põem-se a dançar, tocando os seus tambores.

Oh! com certeza mataram o seu deus e estão sedentos de outro.

Estou nu. Agora vai ser fácil esconder-me nas últimas ramificações do meu subterrâneo... (MACHADO, 2002, pág. 55-56; grifos do autor)

Os aforismos também debatem a questão: "Menos reconhecidos devemos ser aos que nos seguem do que àqueles que se afastam de nós de uma maneira ardente" (MACHADO, 2002, pág. 21), em que o enunciado não dá margem à discordância e tem pretensão de verdade; mas, com mais suavidade, aconselhase não ficar cego ao verdejante e luminoso ao alcance da mão: "Não te embales muito na miragem do longe e do depois, a fim de não perderes o que arde invisível no perto e sopra em silêncio no agora." (MACHADO, 2002, pág. 60, grifos do autor)

Como sintetizou Antônio Dimas: "Generoso, dispersivo e acolhedor, Aníbal Machado viveu a vida literária com a intensidade de quem pouco se importa com a aura depois da morte" (DIMAS, 2001, pág. 6). Além disso, o escritor não tinha pressa de publicar e sempre trabalhou cuidadosa e lentamente na elaboração de suas histórias, o que nos dá a exata medida da importância que ele Ihe atribuía. Quiçá o escritor julgasse que o melhor de si eram as conversas, as sugestões dadas por telefone ou cartas que se perderam, nas domingueiras ou nos artigos críticos. Bem consciente de que "[a] chama do pavio tanto depende do azeite que a alimenta quanto do vento que pode apagá-la" (MACHADO, 2002, pág. 62), pensasse antes que o melhor era multiplicar as faíscas. Para não poucos, porém, a resposta à pergunta que abriu esta seção é simples: a obra magna de Aníbal seria Cadernos de João.

\section{Sobre os Cadernos de João}

Os "inefáveis e singularíssimos Cadernos de João" (ALONSO, 1984, pág. 45), diários sem data, mesclam apontamentos avulsos, devaneio, memória e reflexão. Para Antônio Olinto, os cahiers, "difícil forma literária que, mais que qualquer outra, revela a presença do espectador participante", nascem da necessidade de contemplação motivada pela agitação e brotam num contexto em que se dá "a identidade do pensamento com a emoção", constituindo um gênero literário cuja fonte é semelhante à da poesia tradicional, pois brota de um espanto diante do mundo, mas "separa-se do poema como tal, porque se larga em planos de puro pensamento e se fixa, aqui e ali, em gestos de conselho ou de interpelação." (OLINTO, 1959, pág. 16-17)

A propósito desse trabalho e do único romance de Aníbal Machado, Alfredo Bosi faz referência ao gênero difícil da "prosa de intenções líricas". Maria Clara Machado declarou que Cadernos de João era a obra 
mais filosófica do pai e a preferida dela ${ }^{10}$. "[C]oletânea de anotações, poemas e histórias curtas" (WERNECK, 1992, pág. 38), "aforismos lírico-sapienciais na linha de Valéry" acrescidos de "pequenas fábulas (...) cujo humor e ou non-sense as aproximam (...) de Jacques Prévert" (PAES, 1985, pág. 109), eles não foram alvo de pesquisa sistemática, exceção feita à tese de Marcos Vinícius Teixeira, Aníbal Machado: um escritor em preparativos $(2011)^{11}$.

Observamos elementos de extração modernista: a atenção à imagem gráfica, a linguagem cinematográfica misturada aos diálogos e à poesia, ${ }^{12}$ a estética do fragmentário, o humor. Há a ironia lúdicoparódica: Aníbal Machado, de esmerada expressão em língua portuguesa, como se não o fosse e disso não cuidasse, expõe o seu domínio também do jargão teórico, e o correspondente desprezo aos excessos retóricos: "Depressa, poeta. Chegou o momento fonético. Convoca os teus circunflexos, que os gramáticos estão na porta cobrando os sinais diacríticos..." (MACHADO, 2002, pág. 150)

A estrutura de Cadernos de João apresenta textos esparsos, com ou sem título, blocos de temas agrupados sob uma mesma denominação ("Os Anti-sombra", "Os personagens", "O verbo no infinito", "Se..."), às vezes em divisões maiores, evidenciadas por tipografia diferenciada ("A atividade dos homens", "Topografia da insônia", "ABC das catástrofes" - os dois últimos, com Poemas em Prosa, foram antes publicados separadamente), ora sem vizinhança espacial, ora em contiguidade. Sem índice ou sumário, somos obrigados a reler e folhear o volume para achar de novo uma parte que nos agradou ou para comparar trechos aparentados.

Há também a inclinação surrealista, reiterada pelo próprio escritor, mas à qual, de nossa parte, não nos fixaremos. Se não resta dúvida de que Machado frequentou, leu e apreciou essa vertente, sobretudo em sua matriz francesa, o lapso temporal hoje nos autoriza a relativizar a relevância do movimento em comparação com a simples afinidade com os poetas, ou, antes, com uma sensibilidade para a dimensão extraordinária e simultaneamente comum da existência, onde quer que ela apareça.

Apesar de ser arriscado atribuir características generalizadas ao surrealismo, que variou bastante do contexto francês para o português e o latino-americano (particularmente, o brasileiro), e assumindo um posicionamento bastante pessoal a respeito, traços comuns a vários dos poetas que declararam algum tipo de pertencimento ao movimento são desconformes à personalidade criadora de Aníbal: o ímpeto destrutivo, anárquico e revolucionário; o irracionalismo; a inclinação para o demoníaco, o esotérico e o ocultista; o ódio ao homem e a idolatria da arte; a soberba do artista e o menoscabo ao semelhante; a aversão à norma gramatical e à sintaxe. ${ }^{13}$

\footnotetext{
10 “Para mim, Cadernos é o melhor livro dele. É o mais original." (CARVALHO, 1994) Marcos Vinícius Teixeira defende que essa "é sem dúvida a obra mais curiosa de Aníbal Machado e a mais importante para a compreensão de sua estética do inacabado" (TEIXEIRA, 2011, pág. 47).

${ }^{11}$ Andréa Maria de Araújo Lacerda, em sua tese de doutorado, o espaço ficcional em contos de Aníbal Machado, lista toda a produção do autor (consultar as referências).

12 Cf. TOKIMATSU, Rosana Fumie. O iniciado do movimento: a ficção de Aníbal Machado e o cinema (2017), capítulo 1.

${ }^{13}$ Márcia Coelho (apud CECHINEL, pág. 56) e Francilene Cechinel (2019, pág. 56) chamam atenção para a contradição de Aníbal dizerse surrealista e zelar pela sintaxe tradicional, afastando-se de transgressões formais.
} 
No mineiro prevalece uma dimensão produtiva e positiva ${ }^{14}$, condoída e até certo ponto conformada com a ordem das coisas. Para Aníbal, o humor é a "rebelião tranquila do espírito contra a miséria envergonhada da condição humana" (MACHADO, 2002, p. 37, grifo nosso). Esse sentimento - quer o chamemos de alegria, fascínio ou gratidão pelo dom da vida ${ }^{15}$ - não é inato, mas cultivado, em um labor que vai e vem, com êxito e insucessos, cacos e restauração. No texto de abertura, "Caderno", apresenta-se a obra, pondo relevo a palavra-chave, descontínuo, e ressaltando-se a convergência entre agir no século e na literatura:

Mapa irregular do nosso descontínuo interior, com os fragmentos, vozes, reflexões, imagens de lirismo e revolta - inclusive amostras de cerâmica verbal - dos muitos personagens imprecisos que o animam. Afloramento de íntimos arquipélagos, luzir espaçado das constelações predominantes...

O autor apenas se reserva o direito de administrar o seu próprio caos e de impor-lhe certa ordem na tranquilidade formal das palavras. (MACHADO, 2002, pág. 7; grifos do autor)

Eis a dimensão coletiva do retrato interior que é dele e que ele diz nosso; heterogeneidade e multiplicidade, numa redação retificadora, cautelosa (o mapa é irregular, os personagens são imprecisos, o arquipélago somente aflora à superfície, o luzir é espaçado e mostra só parte das constelações, o autor não tem controle absoluto, o conjunto é um caos, a ordem é relativa, a tranquilidade das palavras é apenas formal, mas, em contrapartida, trata-se de um mapa, documentação de um material rico, abundante). Assim é a vida também: repleta em seus fragmentos, interrupções, sobressaltos, misturas e marasmos.

A linguagem polida exige atenção a reticências, interrogações e exclamações, parênteses e travessões, vocativos, aqui e ali aliados ao imperativo, os recados dirigidos a uma segunda pessoa do singular que está entre uma imagem reflexa do eu que fala e um terceiro dissimulado ${ }^{16}$ ou à primeira pessoa do plural, a mistura de poesia e prosa, não apenas porque na obra constam ambas, mas porque há textos que se negam a uma categorização e são as duas coisas.

Adalberto Luís Vicente, lembrando que "[a] não-linearidade discursiva ou lógica, as rupturas sintáticas, o 'esfacelamento de perspectivas', as digressões pela memória, a mistura de gêneros e a

\footnotetext{
$14 \mathrm{O}$ "ABC das Catástrofes" é exemplo: conquanto o tom predominante seja de perplexidade com a imprudente desmedida humana (motor inadvertido de cataclismos, especialmente os ambientais) e a cega impassibilidade do destino fatal, há ainda a escrupulosa investigação da dinâmica de cada tipo de catástrofe, da reação do indivíduo às situações-limite à contemplação dos escombros e ruínas, da passagem ou suspensão do tempo no instante decisivo à velocidade do restabelecimento do sobrevivente ao mísero egoísmo nosso de cada dia, não há triunfalismo quanto à derrota da humanidade nem exaltação da morte, não há celebração da violência: "Deve-se olhar para os entulhos da catástrofe com o pensamento voltado para as formas belas que eles podem assumir na reconstrução". (MACHADO, 2002, pág. 138) Note-se que a beleza não é certeza, mas possibilidade. Não obstante, a recomendação se mantém.

${ }^{15} \mathrm{Na}$ "Autobiografia", o mineiro, rememorando os anos de boemia estudantil, menciona vivenciar "uma sensação de vazio quando entrava em casa de madrugada, deixando nos companheiros a impressão de que (...) era o mais alegre" (MACHADO apud ANTELO, 1994, pág. 39). Já em Cadernos de João, ele reflexiona nas camuflagens em que incorremos: "Se, dispostos a ouvir de mais perto o rumor da alma de cada um, nos debruçarmos demoradamente sobre a vida do homem tal como ela tem sido em nossos dias chegaremos à convicção de que a quase totalidade das criaturas, mesmo as que parecem proclamar sua felicidade e gritar sua alegria, é secretamente desesperada e incapaz de estar à altura da vida." (MACHADO, 2002, pág. 11)

16 Um exemplo eficiente deste recurso bem drummondiano (a exemplo de "Elegia 1938" e "Os ombros suportam o mundo") é o "Discurso patético a um homem que envelhece": "Tomas do calendário e verificas a idade. (...) Mas, e essas descidas frequentes em ti mesmo, esse avizinhar-se de zonas frias, essa aborrecida direção aos osso?.../ Outrora matavas o tempo, agora o tempo te mata." (MACHADO, 2002, pág. 75)
} 
intertextualidade são alguns dos sintomas textuais do fragmentário presentes na literatura moderna e pósmoderna" (VICENTE, 2010, pág. 118), cita o pensamento de Heráclito nos Cadernos de João, defendendo que toda a obra expressa a ideia de movimento, de mutabilidade. ${ }^{17} \mathrm{O}$ deslocar-se significa, ainda, assumir-se o observador de perspectiva excêntrica, como vemos no fragmento "A festa do cisco":

Antes que o tantã dos últimos foliões entregasse o resto da noite à ablução da madrugada - houve uma festa na pracinha deserta.

As rainhas já se tinham retorcido sobre o asfalto, os bêbados vomitado nos muros.

A praça era um tamborim abandonado.

E como não houvesse ninguém, a brisa se levantou e fez girar tudo o que ficara de confete, poeira e estiradas serpentinas, num movimento macio, e sedoso rumor de coisas... (MACHADO, 2002, pág. 81; grifos do autor)

Os foliões renderam, o mundo parece adormecido e entregue ao abandono. O narrador onisciente, tão distanciado que quase se torna invisível, contempla o curso ininterrupto do tempo e a transformação da festa em feira. No fluir imperturbável da vida, a majestade humana é passageira e reversível, mas a dimensão de espetáculo e beleza nunca desvanece, apenas movendo-se do centro do palco para a periferia das modestas iluminações cotidianas.

No senso comum, cisco é o corpúsculo que, olho adentro, pode dificultar a visão. Mas, da perspectiva cósmica, que é o homem senão minúscula poeirinha sobre a superfície da Terra? No Aulete, entre outras definições, descreve o que a enxurrada transporta, o que se deixa arrastar pela correnteza. Do ponto de vista etimológico, o vocábulo "cisco" é diminutivo de "cinzas", as quais encerram a folia momesca cada ano e, um dia, serão o destino de todo mortal. O pó que somos, contudo, não exclui a dignidade, já que a madrugada, misterioso instante limítrofe entre o dia e a noite, portanto metáfora para a antítese certeza e desorientação, onipotência e desilusão, lava os excessos, purifica e restaura. Sombra de um sonho pindárico, erva e sopro bíblicos, o homem partilha a posição de pináculo da criação e de louca fragilidade solta no universo.

\section{Palavras ao vento}

Entre as coisas que entram no círculo de manipulação do homem, mas não se limitam a ele, Aníbal

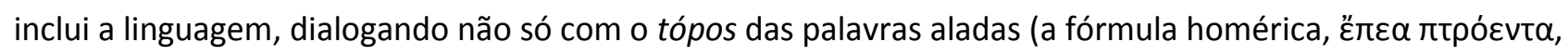

\footnotetext{
17 “O fragmento, tal como o conceberam os primeiros românticos alemães, parece ser um instrumento de análise bastante produtivo para se adentrar criticamente certos textos curtos presentes em Cadernos de João, de Aníbal Machado, uma das obras mais originais da poesia brasileira, tanto pela sua forma, quanto pelo seu lirismo. A coletânea é formada pela reunião de diversas formas fragmentárias: o fragmento propriamente dito, os poemas caleidoscópicos (vários fragmentos reunidos sob um título, cada um deles reverberando um aspecto do tema, cujo exemplo mais brilhante é o poema "Topografia da insônia"), o poema em prosa, o poema dramático, o poema de circunstância, cômico ou paródico etc." (VICENTE, 2010, pág. 121) e ainda: "Na poesia de Aníbal, o deslocarse torna-se mais importante do que o ponto de partida ou de chegada. No tempo percorrido entre um espaço e outro se faz eterno o instante, mas este nunca encontra sua fixidez, pois no universo em que tudo flui não existe nada que possa ser considerado estável." (VICENTE, 2010, pág. 124)
} 
pode ser vertida por "palavrório voador"), mas com leitura específica, que especula sobre a coesão do discurso ${ }^{18}$. É o que vemos em "Desembarque do poema":

Umas não sabem a que vieram. Outras procuraram o apoio de uma frase familiar após o celibato no silêncio. Erguem-se outras em curtos voos de ensaios na transparência do espaço.

Cada palavra não diz logo o que pode, mas espera. Espera o momento. Suspeitam, todas, que vieram para alguma coisa, mas falta ainda o plano. Esta vive da memória de algum poema do qual se desgarrou; aquela parece virgem de qualquer aventura e tem pressa de servir.

Vão adejando na claridade... Distribuem-se em desordem pelo espaço mental. Algumas pousam na pedra do cais e - objetos usados - ali se deixam ficar ao sol.

Olham-se. Olham para a paisagem. As que andavam juntas retomam sua autonomia, não mais voltarão a reunir-se à criação desfeita.

Se tentam agarrá-las para nova vida comum, esquivam-se, prometidas a próximas alquimias.

Estão soltas, em férias. Nada significam ainda. E enquanto esperam ser chamadas ao silêncio do poema, adejam livres na luz de limbo, anteriores ao mistério que ainda vão gerar. (MACHADO, 2002, pág. 10)

As palavras se mostram ao poeta, portanto, na multiplicidade de atitudes, na mobilidade, na volubilidade. Em Aníbal o todo é iluminado: ${ }^{19}$ na "transparência do espaço", "na claridade", "na luz de limbo", "ao sol", as palavras "têm pressa de servir" e "esperam ser chamadas ao silêncio do poema", mas é preciso abordá-las com brandura, sem ferir sua liberdade ("Estão soltas, em férias"!), do contrário podemos presenciar uma revoada.

No curso regular da frase pode uma palavra, uma imagem ou um movimento imprevisto assumir a força de uma aparição e iluminar subitamente toda a estrutura verbal. O que era neutro e opaco passa então a irradiar. Como se as palavras esperassem a privilegiada, portadora do elemento mágico que leva a todas a transfiguração da poesia. (MACHADO, 2002, pág. 11)

A paciência é necessária, mas a própria palavra, no enlace com outras, atravessa por inteiro o criador (tornado espaço onde elas flutuam), e de repente, inflama o trivial.

As palavras que te vão servir; as mais nuas; as que, apesar da ganga de reflexos mortos de que são portadoras, ainda não perderam a pureza e irradiação originárias - essas palavras só chegarão ao teu poema depois que afastares aquelas ou a combinação daquelas que tamanha confusão e barulho costumam fazer à estrada de teu espírito. (MACHADO, 2002, pág. 24)

Os termos podem-se amortecer, entibiar-se, sobrecarregar-se do supérfluo ou tornar-se desgastados, prostituídos; há que revigorar as palavras já desgastadas, fugir daquelas que se fizeram moeda corrente e abraçar as que ainda luzem: a arte se faz sem alarde. "Retira do teu poema as estridências do grito, se queres que ele tenha mais alcance e ressonância" (MACHADO, 2002, pág. 59), uma proposta que,

\footnotetext{
${ }^{18}$ Com significativas diferenças, esse lugar-comum é explorado por Machado de Assis, em "O cônego ou metafísica do estilo", e, curiosamente, por Augusto Meyer, na sua explicação do que é o enjambement: "Pela sua própria função gramatical, o adjetivo parece querer dizer ao leitor, no fim do verso: eu não sou uma palavra cortesã, sou uma honesta burguesa, fantasiada de rima, sou casada e ando de braço com aquele senhor substantivo, que espera por mim no princípio da linha seguinte. Diz e logo estende a mão, para que o leitor atencioso a conduza aos braços do marido." (MEYER, 1986, pág. 259)

${ }^{19}$ A preferência pela imagística recorrente da luz (à qual se deve somar a percepção da sombra e do obscuro, como contraparte) é apontada por Cavalcanti Proença e Antônio Dimas, referindo-se especificamente a "Viagens aos seios de Dúlia" (PROENÇA, 1974, pág. xxxiv; DIMAS, 1985, pág. 67), e por Elza Miné, que analisa o recurso como um traço da linguagem cinematográfica em Aníbal (MINÉ, 1984, pág. 11).
} 
com demandar despojamento, defende revoluções silenciosas, sem escândalo, sem escarcéu. Oxalá, não as impossibilite o poeta: “A imagem poética, em súbita aparição, já vem com os ritmos orgânicos que a prendem a todo o sistema do Universo" (MACHADO, 2002, pág. 107; grifos do autor), mas o "artista do verso [é] muitas vezes inimigo inesperado da poesia..." (MACHADO, 2002, pág. 28), ou simplesmente agente da passiva, como lemos em "Quase":

\footnotetext{
Eis que num sussurro de asas vinham descendo os elementos da coisa a ser criada. Não eram apenas imagens gratuitas ou aproximativas, mas elementos comprometidos numa constelação implícita, ainda sem céu para começar a compor-se e fulgurar. Ao poeta cabia agora a sua parte de artista, mínima, que só ela bastava para a evidência e esplendor do objeto pressentido. Nega-se, porém, o poeta a intervir, temendo que a qualquer aceno seu as imagens debandassem ou que se turvasse a pureza de seu espaço de voar.

Que por si mesmas, em livre e aéreo movimento, tecessem elas o poema gratuito... Mas fugiram as imagens! Fugiram para tornar em seguida.

Dessa vez, insistindo mais. E tão familiares e amadurecidas, que já antecipavam as palavras e ritmos da obra prefigurada.

O poeta limitou-se apenas a apreciar o prodígio.

Quase... (MACHADO, 2002, pág. 49-50)
}

O mineiro pendura a narrativa nas reticências, sem decretar a derrota definitiva de quem deixou o poema escapar. A gramática da vida ordinária invade o pensamento poético e arrasta Aníbal sempre para a vida. O papel do artista é ínfimo: aguardar o instante, assistir ao voo, tentar não destruir nada, limpar a área para que os elementos da coisa criada circulem e unam-se, insistir, apreciar o prodígio, sem a pretensão de apanhá-los entre os dedos.

\section{Que remédio? Só rir}

O riso, em Aníbal Machado, é o tempero apropriado para um texto que poderia parecer ou ser enfadonho em seus conselhos e recomendações ou vácuo em suas pretensões sapienciais, considerada a incongruência e a desordem que nos cerca. Com ele, o tom imperativo se dilui:

Com sete ou setenta anos, deve-se esperar um presente. Esperá-lo sempre. Até o fim da vida... Mas que não seja a morte.

Se alguém abre a porta ou bate a janela, nunca pensar noutra cousa.

Não é necessário que seja objeto raro ou delicado. Basta que seja um presente.

Pode vir do horizonte, pode vir do vizinho.

Um brinquedo, uma garrafa, uma fruta, um bicho, uma flor - tudo serve. O principal é que não seja desembrulhado logo. E que venha amarrado em fios de ouro, envolto em papel irreal.

Para se manter em estado de presente puro.

O presente dura até o momento de ser aberto. Depois morre. E espera-se outro.

De cada trem que chega, avião que pousa, carruagem que passa, de alguém que entra ou navio que atraca - deve-se esperar sempre um presente.

Se não vem, não faz mal. É até melhor, espera-se com mais força.

Começa-se a desejá-lo com tamanha intensidade, que a dúvida não está em saber se vem (oh! é evidente que virá), mas em descobrir a natureza e a forma que há de ter. (MACHADO, 2002, pág. 169) 
O poema em prosa "O presente" ainda continua. E na frase "de cada trem que chega", quem nasceu em Minas reconhece um patrício no anfitrião que abriu sua casa para uma multidão de gente e ainda hoje surge apenas com discrição na literatura brasileira: homem em preparativos, provisório definitivo, passageiro de carona no grande clandestino, "Viajante sem passaporte":

Enfim, o que importa é o frêmito da partida; a pista, a praia e a plataforma se afastando... a palpitação das águas no sulco distante da popa... O que importa é a esperança vaga do encontro (que encontro?) alimentada pelo perpétuo adiamento da chegada. (MACHADO, 2002, pág. 24)

Toda a obra de Aníbal parece pôr em xeque continuamente a idealização segundo a qual o artista é um predestinado exilado em meio a pedestres incapazes de valorizá-lo para, ao contrário, exigir dele uma postura ativa e sóbria frente aos desafios cotidianos. Não se nega que Machado atribua uma vocação e um chamado exclusivo ao poeta, mas as consequências desse dom não são as mesmas. Ei-lo expondo os nossos subterfúgios em "O grande sofisma":

Não sou responsável pelas minhas insuficiências. Se minha corrente vital é acaso interrompida e foge de seu leito; se meu ser muitas vezes se desprende de seus suportes e se perde no vazio; se é frágil a minha composição orgânica e tênues os meus impulsos - culpo disso os meus pais, a sociedade, o regime, os colégios; culpo as mulheres difíceis, os governos, as privações anteriores; culpo os antepassados em geral, o mau clima da minha cidade, a sífilis que veio nas naus descobridoras, a água salobra, as portas que se me fecharam e os muitos "sins" que esperei e me foram negados; culpo os jesuítas e o vento sudoeste; culpo a Pedro Álvares Cabral e a Getúlio; culpo o excesso de proibições, a escassez de iodo, as viagens que não fiz, os encontros que não tive, os amigos que me faltaram e as mulheres que não me quiseram; culpo a D. João VI e ao Papa; culpo a má-vontade e a incompreensão geral. A todos e a tudo eu culpo.

Só não culpo a mim mesmo que sou inocente. E ao Acaso, que é irresponsável... (MACHADO, 2002, pág. 11)

Em resposta ao que se quis e não veio, a sucessão de negações e afirmações condicionadas se completa com uma ação: o verbo "culpar", em primeira pessoa e no tempo presente, tem como objeto direto uma série heterogênea de categorias distintas, abstratas, concretas e hipotéticas. A voz que fala se reconhece falível, mas só depois do "se", impondo ao leitor uma lógica que, à medida que lemos, se comprova ilógica. Quando se trata do eu, as palavras são suaves e há indulgência para as "insuficiências"; quando é a vez de pôr em questão agires alheios, medida diversa...

A ironia já se exibe no título, que reúne tudo sob a égide de uma falácia. Se o escritor ri de todo aquele que peremptoriamente se isenta de culpas, em momentos mais bem-humorados, a desculpa é ridicularizada: "E se acaso tropeço, não é contra as pedras, é contra a minha sombra." (MACHADO, 2002, pág. 35) Trocando em miúdos, é a minha a própria obscuridade diante da luz que me faz cair; contudo, para apontar a sombra, deve-se perceber a luz. E aqui, voltando à nossa metáfora, vida e obra são, simultaneamente, sombra e luz. Ora se iluminam mutuamente, ora escapolem entre os dedos. O que importa é instaurar o jogo entre essas duas realidades: "Enquanto tarda a infalível claridade, vai-te arranjando com a que destilares da sombra comprimida." (MACHADO, 2002, pág. 24; grifo nosso)

Uma reflexão que traduz essa mesma ideia, já sem o teor cômico: "Não maldigas a vida em geral em nome da tua, contrafação da que sonhavas. Trata de pôr na escala da terra os teus sonhos, e em termos de 
sonho a tua vida." (MACHADO, 2002, pág. 65) São palavras de quem já andou e conhece um bocado de chão. Não vem ao caso saber de quem é a culpa e, no esvaziar-se desta indagação, outras revelações interessantes se colocam: "Teu inimigo de certo modo te pertence: é um dos teus aspectos" (MACHADO, 2002, pág. 165)

As disputas quanto à responsabilidade se postam à espreita tão logo se adentra, como já dissemos, o "ABC das Catástrofes". Mas, não obstante a imagética dos cataclismas aí se multiplique, os restos derruídos, recordamos, comparecem em toda a extensão dos Cadernos de João, ora de forma construtiva, ora realçando a desordem e as vítimas, aqui como o desastre interior, ali como o acidente fatal: desmoronamento, explosão, inundação, queda aérea, descarrilamento, incêndio, desabamento, demolições.

Essa sensibilidade também tem lastro na experiência. Na Autobiografia, o escritor confidencia que, malgrado já tenha sofrido dois grandes desastres, "insiste" (MACHADO apud ANTELO, 1994, pág. 47). Drummond, em homenagem, afirma que o amigo provou-se destemido, "inclusive no avião de que se desprendeu a hélice e em cujo interior ele, sem fraquejar, amparou o companheiro de pernas decepadas, em agonia" (ANDRADE, 1984, pág. 1).

Sendo "esse incorrigível que tão bem vive e se arranja em meio aos destroços do palácio imaginário que the caiu em cima", o " recuperador da presença perdida" (MACHADO, 2002, pág. 23-24, o criador não perde tempo com queixas, pelo que não foi ou poderia ter sido; tudo ao seu redor se presta a edificações vindouras. Se for preciso escolher, Aníbal é mais de "Quem avisa amigo é" que de "Se conselho fosse bom, ninguém dava; vendia". Todavia o vivido deve vir em frações aceitáveis, para não sobrecarregar o peito e o corpo, substância e veículo por que passam os tempos:

Com a volta da esperança, perdemos aos poucos a antiga amargura e a força do grito. Já não sabemos blasfemar. Aquilo que nos habituamos a combater se desfaz ante as primeiras arremetidas do espírito livre, à luz da nova claridade. Já não há mais razão para a revolta. E o desespero não se cultiva como pérola falsa.

Mas no cerne da alma dói ainda a velha cicatriz. O que outrora nos fez sofrer vem reclamar participação no que agora nos faz esperar. E a anacrônica interferência torna assim ambíguo o nosso canto. Canto que os mais jovens se incumbirão de purificar... (MACHADO, 2002, pág. 142143)

É assim que, nos Cadernos de João, a profissão de fé ganha uma afirmação poética: “Homem, não te preocupes com o sono do caranguejo: cada vez que à tua janela brilha o sol, uma paisagem se inaugura para os outros; cada vez que nasce uma criança em teu quarteirão, um tempo novo começa a correr para alguém." (MACHADO, 2002, pág. 75)

\section{Imperativos, iniciativas}


Falamos da recorrência dos comandos (realizados por meio dos modos imperativo ${ }^{20}$ e subjuntivo, ${ }^{21}$ pelo infinitivo, ${ }^{22}$ pela voz passiva ${ }^{23}$ e pelo uso do condicional ${ }^{24}$ ), mas o sabarense não abdica da liberdade. As ordens às vezes são para o próprio poeta, e em outras reflexões dirige-se o escritor a um "tu" que pode ou não coincidir com ele mesmo, numa releitura do experienciado e no esforço de compreensão de si. É melhor ser indulgente com todos, até com o nosso eu mais verde, mas sem deixar de dizer o necessário:

Nunca peças conta, na idade viril de teu espírito, às angústias da mocidade. Nem te envergonhes do tempo da ardente aprendizagem, quando usavas subterfúgios para proteger tua timidez. Nada de infame nesses expedientes. Apenas um recurso dilatório à tua afirmação final. (MACHADO, 2002, pág. 44)

Os comandos no infinitivo permeiam "Iniciativas", um dos últimos textos de Cadernos de João. Temos uma ideia de sua importância para o autor quando descobrimos que ele já havia sido publicado separadamente em 1953, numa plaquete feita de modo artesanal por Mario Fiorani e Alfredo Albieri cuja tiragem, para circular apenas entre os amigos e parentes, foi de 57 cópias. (TEIXEIRA, 2011, pág. 47)

Faça o que lhe digo. Solte primeiro uma borboleta.

Se não amanhecer depressa, solte outras de cores diferentes.

De vez em quando, faça partir um barco. Veja aonde vai. Se for difícil, suprima o mar e lance uma planície.

Mande um esboço de rochedo, o resto de uma floresta.

Jogue as iniciais do lenço. Faça descer algumas ilhas.

Mande a fotografia do lugar, com as curvas capitais e as cópias dos seios.

Atire um planisfério. Um zodíaco. Uma fachada de igreja. E os livros fundamentais.

Sirva-se do vento, se achar difícil.

Eles estão perdidos. Mas nem tudo o que fizeram está perdido.

Separe o que possa ser aproveitado e mande. Sobretudo, as formas em que o sonho de alguns se cristalizou.

Remeta a relação dos encontros, se possível. E o horário dos ventos.

Mande uma manhã de sol, na íntegra.

Faça subir a caixa de música com o barulho dos canaviais e o apito da locomotiva.

Veja se consegue o mapa dos caminhos.

Mande o resumo dos melhores momentos.

As amostras de outra raça. (MACHADO, 2002, pág. 177)

O poema alterna a exigência com o lirismo; o rigor da frase com a leve sensação de um deslocamento agramatical, com verbos que pediriam objeto indireto e estão desprovidos deles ("mandar", "atirar", "remeter", "lançar") ou que demandam informações espaciais que não constam do texto ("faça descer",

\footnotetext{
20 É o caso do miniconto/poema em prosa "Noite numa folha" (MACHADO, 2002, pág. 174-176) e de trecho sem título: "Não te empenhes na exclusividade do que descobres. Pertence a todos./ Na superfície das águas ou no azul do céu tuas iniciais não se gravam." (MACHADO, 2002, pág. 77)

${ }^{21}$ De "Material de Construção": "Os amantes rompidos jamais deveriam devolver as cartas de amor. Nem queimá-las. Elas não lhes pertencem. Pertencem ao universal 'Monumento ao Amor', nunca terminado..." (MACHADO, 2002, pág. 38; grifo nosso); no subjuntivo ("que o teu canto, poeta, lançado ao mundo, sirva de fermento...");

22 São exemplos os vários textos chamados "O Verbo no Infinito", de que citamos um: "Olhar bem para as coisas que de repente deixaremos de ver para sempre." (MACHADO, 2002, pág. 10), "Não se apoderar daquilo que se descobre. Nem esconder. Mostrar aos outros. Passar adiante..." (MACHADO, 2002, pág. 66).

23 De "Armistício": "Ordem de cessar o fogo. Recolham-se os feridos. Transformem-se as carabinas em bengala branca de cego. Aos mutilados, como prêmio, seja concedido o direito de pedir esmolas."” (MACHADO, 2002, pág. 74)

${ }^{24}$ Citamos um dos fragmentos intitulados "Se...", neste excerto que mais uma vez retoma o tópos da fama como presente de grego e ilusão: "Se queres penetrar intimamente na alma de uma cidade, evita-lhe os homens importantes, e pergunta a qualquer transeunte de suas ruas: 'Quais os desconhecidos mais interessantes deste lugar?'” (MACHADO, 2002, pág. 61)
} 
"faça subir"), frases sem verbo e sentenças que resistem à interpretação. Não se trata, portanto, de passar diretivas, mas de abrir sugestões e possibilidades, aguardando uma resposta cuja meta é exterior às palavras: o amanhecer, o mar, a planície, a floresta, os ventos, as curvas e os seios; mesmo a matéria dos sonhos deve ser cristalizada.

Com tais predicados, Aníbal não poderia ser fundador nem fâmulo de uma escola. O sestro de corrigir, refazer, reformar os manuscritos é, além de um acerto de contas com o passado, esforço mais higiênico que criativo, premido menos pelo que concerne a projetos idealizados do que para despojar-se de assombrações, já que o essencial está em quem é vivo:

Limpa de vez em quando as tuas gavetas, ninho de fantasmas. Queima os papéis velhos, os arquivos mortos.

Ajuda o esquecimento a esquecer...

Antes o virgem vazio do que a sufocação dos entulhos. Que em tua cabeça as ideias não se imobilizem nunca em arranjos de museu, mas fermentem para novas metamorfoses. Chegarás assim à maturidade, ainda com direito aos últimos fulgores da vida. (MACHADO, 2002, pág. 146)

Pareceria contraditório, diante da recomendação para não destruir as cartas de amor. Mas ele especifica: limpa de vez em quando as tuas gavetas. Em outras palavras, dispense apenas o que não presta, o que engessa e asfixia. $O$ poeta quer movimento, não paradeiro.

\title{
Bichos, árvores e pedras
}

Da abertura ao desfecho, Cadernos de João é povoado do mundo natural. Sua petição inicial, devedora de uma adolescência na qual, como já vimos, "[h]avia muita coisa que descobrir fora dos livros, no mundo que nos cercava" (MACHADO apud ANTELO, 1994, pág. 37), é fabricar

\begin{abstract}
Uma coisa entre herbário e casa de pássaros, com nascentes de água no branco das páginas, e rumor de concha marinha em cada frase. Uma coisa em polpa de fruta, o sumo escorrendo entre as rachas; que ameace fugir das mãos para mergulhar e voar; que nos destrua à noite e nos ressuscite esquecidos da véspera; que nos faça amanhecer muitas vezes.

Um livro que esteja ventando em cada folha e fazendo sol nas margens. Um livro que suscite no leitor a vontade de fechá-lo depressa e ir vivê-lo fora de suas margens. (MACHADO, 2002, pág. 107)
\end{abstract}

Raúl Antelo, ao realçar que em Aníbal há sempre um terceiro que harmoniza os contrários, aponta as metáforas recorrentes do vento e da pedra, que, dando forma a polaridades como fluidez $\mathrm{x}$ dureza, sonho x realidade e mobilidade x fixidez, "resistem à significação unívoca" (ANTELO, 1994, pág. 19). Igualmente a luminosidade só de raro em raro se afasta.

Elevar a temperatura do espírito ao nível de fusão dos resíduos calcificados; purificar os sentidos até que o Universo se deixe surpreender em seu estado de virgindade original; dilatar as fronteiras de nosso espaço interior, não por ocupação colonizadora, mas excitando ao voo os pássaros nele adormecidos; aquiescer ao apelo numeroso das coisas; promover à condição de árvore o que dentro de nós se esfria em pedra, e à condição de vento o que se esgalha em árvore: ritos preparatórios, íntimas providências, preliminares silenciosas à chegada da Poesia. (MACHADO, 2002, pág. 67) 
A biologia, no sentido do saber sobre a vida, constitui fonte de metáforas ${ }^{25}$ de profundo significado afetivo, frequentemente de restabelecimento:

Se, para ser e florescer, a planta ainda sem nome tivesse que esperar o batismo da palavra, que seria de nossos campos? No Brasil de botânica subversiva, como designar as coisas do mundo vegetal, se em cada região não muito afastada das outras a mesma flor, a mesma árvore, muda de nome e de costumes, e se outras que se oferecem ao nosso êxtase adotivo irrompem anônimas filhas "ilegítimas" da terra, do vento e do sol?

A nomenclatura erudita só serve para torná-las mais desconhecidas, e como que lhes arrebata a cor e o cheiro.

Quando pronunciamos a palavra "rosa" ou a palavra "jasmim", reponta-nos logo aos olhos um jasmim ou uma rosa em sua totalidade luminosa e trescalante; mas no que toca a essas flores e plantas ainda sem batismo, é preciso indicá-las num quadro circunstancial: "aquele galho que colhemos à margem do regato em fins de julho"; "aquela flor azul de estrias douradas, que uma vez puseste no teu colo, depois da chuva..."

Ó vegetação à margem dos dicionários, êxtase e aflição dos amantes! (MACHADO, 2002, pág. 94)

As rimas (ser/ florescer, rosa/luminosa), assonâncias e aliterações (Brasil de botânica subversiva, muda de nome e de costumes, se oferecem ao nosso, nomenclatura erudita, logo aos olhos, totalidade luminosa e trescalante, galho que colhemos, à margem de um regato, margem dos dicionários), por exemplo, as perguntas retóricas, a descrição sensorial, o vocativo, a apagada lembrança intertextual ("nossos campos", "a flor azul", a rosa e o nome, mitologias). Todavia, nessa conversa de flores, um dos temas mais batidos em se tratando de amores, o escritor se refere a toda uma tradição literária brasileira e a polêmicas incendiárias envolvendo justamente a natureza. Rechaçando os exacerbados que cultivam tão somente o nacional e o autóctone pelo perfilhamento carinhoso das espécies estrangeiras e também a faina taxonômica, tentativa de inventariar algo que não é nem deveria ser nosso, a natureza, o trecho defende que a forma de possuir essas alegrias é guarda-las na memória ou transformá-las em poesia.

Além dos elementos da paisagem há outro reino: galos, cães, peixes, bois, cavalos, "sapos e vagalumes" (MACHADO, 2002, pág. 87), insetos, passarinhos. O bestiário reúne seres declaradamente literários, como o abutre de Prometeu (MACHADO, 2002, pág. 20) e a Esfinge (MACHADO, 2002, pág. 12, 22, 178), metafóricos, como o dragão e dos morcegos da insônia (2002, pág. 118, 105). O rio Amazonas, como um "leão do deserto", raramente se enfurece (MACHADO, 2002, pág. 138), a morte "anda pastando pelas imediações" (MACHADO, 2002, pág. 70), a guilhotina é uma girafa (MACHADO, 2002, pág. 115) e a escavadeira um mamute (MACHADO, 2002, pág. 98). Outra natureza possui uma "uma aranha, talvez caranguejo" que se instala na zona do som garganta, "onde mergulhava devagar os tentáculos prolongados", impedindo o grito e impondo uma contradição entre a força do pensamento e a fraqueza da voz.

\footnotetext{
${ }^{25}$ Mencionamos, para comprovação: “No frágil tronco da vida”, "Ele viceja na idade em que as aparências...", "Aquele jovem será ainda por algum tempo agreste e puro", "Ó sabedoria dos maduros, irriga a tua aridez...", "a insônia está lavrando...", "O perigo limpou subitamente o campo", "O inimigo começa a murchar...", "Tem sementes de rugidos...", "homens que me queriam afogar, pensando que eu ia roubar-lhes o capim", "Enxertá-los no comprometido tronco e ajudá-los a brotar e crescer", "crescera como planta", "Nunca negues os teus fecundantes às suas raízes definhadas", "o espírito da vida soprou novas sementes no campo de cinzas", o célebre "Verdejou, pessoal!", para indicar, por perífrase, que as chuvas molharam o solo no nordeste, "a rosa aberta do dia", "a mão que nas minhas senti como pétala de rosa".
} 


\section{Aforismos, desvarios}

Cadernos de João pulula de aforismos oraculares, que se prestam a diversas situações, prodígios de concisão que vão da vertente mordaz e divertida à sentenciosa, servindo-se recorrentemente da ambiguidade, do riso ou do jogo de palavras para comunicar com agudeza o que os pequenos confins demarcados pelas palavras não deixam à primeira vista antever:

Há burrices que, de tão humildes, chegam a ser pureza e têm algo de franciscano. Outras há, porém, tão vigorosas e entusiásticas, que conseguem imobilizar por completo o nosso espírito para a contemplação do espetáculo. (MACHADO, 2002, pág. 110)

Há indivíduos, anônimos e obscuros, que nos surpreendem pela sua grandeza quando os tratamos de perto. Outros, que só nos parecem grandes quando vistos de muito longe: o contrário das estrelas. (MACHADO, 2002, pág. 109)

Não é triturando a concha para examinar-lhe a substância, é levando-a aos ouvidos que se descobre mais depressa a essência do mar (MACHADO, 2002, pág. 151)

No desastre instantâneo há uma fulguração que não é do sol nem de nenhuma luz exterior (MACHADO, 2002, pág. 139)

O incêndio é a mais impaciente das catástrofes; a explosão, a mais impulsiva e lacônica; o abalroamento, a mais colérica; a inundação, a mais feminina e majestosa (MACHADO, 2002, pág. 136)

O potencial dessas frases, por vezes de retórica substantiva, ${ }^{26}$ se esconde no elíptico da expressão e seu encanto é diretamente proporcional à dificuldade de dar-lhes um emprego funcional na arquitetura argumentativa de textos estranhos ao seu contexto de origem. Ousamos dizer que, por se recusar a uma pura assimilação, tais trechos se afirmam como citação e fragmento, fortalecendo sua atração como enigma e nó.

Curiosamente, no caso de Aníbal Machado, o uso de afirmações categóricas como essas, tão próprias da maturidade afasta-se, não obstante, do amargor arrogante da experiência. Existe algo no pensamento do prosador que the permite, sem pejo, voltar ao que é novo com perplexidade infantil e entregar-se à possibilidade de recomeçar, via de regra reconhecendo que a solidão, posto que inevitável, nunca é absoluta e, aliás, oferece perigos: “Ninguém pode abrir sozinho o seu túnel pessoal para a claridade do dia, sem o risco de morrer sob os entulhos." (MACHADO, 2002, pág. 28).

Há, por conseguinte, uma generosa dose de paciência, estendida aos homens, ao mundo, a todas as eras e gerações (“O espírito só tem uma idade: ou é sempre jovem ou não é espírito./ Tudo mais é arquivo ou reminiscência." MACHADO, 2002, pág. 88); e paciência repassada da consciência da finitude e do que devemos, como filhos, à nossa própria época: “A reverência aos 'novos' é uma homenagem à esperança, quase sempre decepcionada, do que possam eles vir a ser no futuro." (MACHADO, 2002, pág. 58) Declarações

\footnotetext{
${ }^{26}$ Denominamos assim sentenças descritivas sem verbos sucedidas por outras que desenvolvem a ideia proposta, também sem o auxílio de formas verbais. O efeito dessa tática, usual nos aforistas, é o hermetismo, amiúde refratário a uma interpretação imediata e única e um acúmulo de ideias: "Aproximação dos polos mortíferos por um movimento contínuo de avanços e recuos. Perigoso divertimento, tauromaquia abstrata dos desesperados..." (MACHADO, 2002, pág. 62)
} 
cautelosas, moduladas pelas aspas, pelo "quase", pelo uso do verbo "poder" e da locução "vir a ser" projetados para o futuro: o homem que fala não tem muitas certezas. $\mathrm{O}$ aforismo frequentemente se converte numa modalidade de conselho que não se prende no visco da banalidade:

Não seja o orgulho que te separe dos outros. Nem a diferença, fácil de ser abolida. Eles não são menores, estão apenas esquecidos do que poderiam ser. Não te ponhas a reprová-los nem a aplaudi-los. Nunca negues porém os teus fecundantes às suas raízes definhadas. E persevera no teu exemplo até a evidência final. (MACHADO, 2002, pág. 67)

O equilíbrio se lê no uso do imperativo aliado a partículas atenuantes - a relatividade das coisas, a sintaxe indireta, a presença de frases negativas, como a exercer uma correção retificadora, que espera do interlocutor, a quem se fala com afabilidade e confiança, uma conduta irrepreensível e sacrifício abnegado quase sobre-humanos, e a indulgência do eufemismo ("estão apenas esquecidos do que deveriam ser").

Recolhe-te em ti mesmo quantas vezes puderes, fugindo às várias frentes da comédia humana aonde foste levado a figurar. Não desprezes porém os seus espetáculos, por te parecerem vulgares ou vazios. Separa neles o que possa exaltar as razões de tua solidão provisória.

Há que aprender ali. Até mesmo na maneira com que o sentido da grandeza é esquecido pela vulgaridade e tolice dos homens. (MACHADO, 2002, pág. 77)

As ações de "recolher-se", "fugir" e "separar" evidenciam o quanto a intimidade com os outros pode ser enfadonha ("vulgaridade", "vazios", "tolice") e o quanto existe de fingimento, encenação, escândalo ou exagero ("comédia humana", "espetáculos") nas pessoas, mas nem isso deve nos remover de sua presença, pois é ocasião de aprendizado e incrementa a força dos argumentos para sustentar a necessidade de, por vezes, ficar só ("solidão provisória"). É que, por sermos incoerentemente múltiplos, nunca estamos perfeitamente sós.

Não somente andamos por várias regiões e atmosferas, como também, dentro de cada um, somos muitos a fazê-lo. Depois é que damos a palavra a um de nós, que passa a exprimir-se em nome de todos e que, usando a mesma sede corporal, os resume e dirige formando a nossa personalidade. (MACHADO, 2002, pág. 154)

O problema é que podemos ser má companhia, como vemos em "A insurreição dos internos", um texto de caráter híbrido, entre (micro)conto, fábula e poema em prosa. Tudo começa com a autorização, pelo narrador, da entrada dos seus piores inimigos ("Bandidos, cafajestes, estúpidos, luxuriosos, seres de suja procedência instalaram-se em mim sem a menor cerimônia."; MACHADO, 2002, p. 170), com a única finalidade de exercitar e pôr à prova seu poder de resistência. Os inquilinos começam, contudo, a provocar desordem e a franquear espaço a outros, numa "invasão fria, viscosa" (MACHADO, 2002, pág. 171).

O combate contínuo acaba por exaurir o dono da casa, que, afinal vergado, é por fim seduzido: "Inútil disfarçar: o gosto, a atração do crime começaram a possuir-me. Entrei no ciclo dos meus demônios. Declarei guerra aos homens, quebrei minha fachada, perdi as condecorações./ Em cada canto de meu corpo um 
animal feroz armava o bote." (MACHADO, 2002, pág. 172) Seguem-se a isso transgressões crescentes. ${ }^{27}$ Esse percurso, no entanto, é interrompido subitamente por um prenúncio de arrependimento precipitado por um episódio imprevisto: "Não sei em que cidade, fui retirado, pela madrugada, de um lago de sangue no chão de um bar." (MACHADO, 2002, pág. 173) Levado a uma policlínica, o narrador duvida do exorcismo improvável, reputado meio "ridículo para o número de hóspedes que carreg[ava], e o mundo de forças que desencade[ava]." (MACHADO, 2002, pág. 174) Mas, contra os prognósticos, a tentativa funciona:

Os aparelhos de vácuo foram colocados. Meteram-me um tubo pela boca, para a sucção. Eu ia vomitar. Vomitaria os monstros que animaram aquela semana de minha vida.

Dentro em pouco, eles ficaram se mexendo na grande bola de vidro.

E na madrugada que vinha raiando, eu era um ser inocente e tranquilo a sorrir para o sol!... (MACHADO, 2002, pág. 174; grifos do autor)

Esse raciocínio reaparece na "Topografia da Insônia", cujo último texto, "As Reuniões", fala de ideias "que provêm de regiões mais opacas", "uma espécie de larvas que se criam numa zona em que se faz noite na gente", que invade e desorganiza, fazendo o narrador exclamar: "Oh, como conseguir a unidade em meu ser? Como pacificar a minha federação?" (MACHADO, 2002, pág. 128; grifos do autor)

\section{Sono solto}

Na "Topografia da Insônia", Aníbal Machado reúne ponderações sobre o sono ou a ausência dele, sonhos e tudo o que cerca a noite. O que se nos oferta é uma delineação minuciosa de um espaço simbólico, anômico, não delimitável, uma extensão em que se está sem estar, na qual não se encontra repouso. Assim, a topografia da insônia nos dá os altos e baixos de uma terra inóspita, os cursos e recursos do pensamento para vencer um adversário invisível (o sono ou a falta dele), sob a duvidosa perspectiva de quem não sabe muito bem onde está e para onde vai.

Os 42 fragmentos, normalmente curtos, podem ser lidos como uma só narrativa, desenovelada por um mesmo personagem que, na de vigília semidesperta, discorre sobre aquilo mesmo que o mantém, contra a vontade, acordado. Para isso concorre a organização dos textos, emoldurada a modo de conversa (solilóquio?) - “O pior não é ficar sem dormir; é permanecer todo o tempo deitado, a poucos centímetros do nível do sono" (MACHADO, 2002, pág. 117) - e encerrada com a capitulação final: "Desisto de tudo... desapareço... Agora é dormir... dormir..." (MACHADO, 2002, pág. 126)

A noite é potente, mas não acachapante. "Todos os navios em todos os mares mal conseguem sustentar o peso da noite que cai sobre as águas" (MACHADO, 2002, pág. 69) A articulação noite e água, dois mistérios, aparece em "O saldo da noite", poema em prosa solto em que, como numa nova narrativa do dilúvio, todo o mundo renasce quando o elemento líquido da noite vai recuando:

\footnotetext{
27 Prova de que Aníbal não é propriamente otimista, mas sensato, é o fragmento sem nome a seguir: "Era uma noite em que se berganhavam germes de podridão. O espírito maligno envenenara a atmosfera. Destruímos os melhores amigos, as ideias mais caras. Profanamos a mulher amada. E retiramo-nos, abatidos, muito abaixo do nosso nível, cada um se preparando para uma insônia de remorsos e morcegos." (MACHADO, 2002, pág. 105)
} 
A cama ainda persistia meio irreal, mas era agora como uma ponte sem margens para ligar. Porque o sono interrompido já estancara a corrente do sonho. A cama perdera os últimos vestígios da constelação destituída. Só muito depois, quando as águas baixaram, é que foi aparecendo o contorno do travesseiro, os lençóis - sinais indiscutíveis da realidade usual.

E das dimensões ilimitadas de há pouco sobrou aquele mesquinho espaço, zona restrita do linho. (MACHADO, 2002, pág. 52-53; grifos do autor)

Quando se escoa o sono, o fluxo dos sonhos é cortado e todo o magnificente elixir em que se flutuava é filtrado. Ao amanhecer, tudo volta ao normal. Por isso é que o poeta, tão cioso do sol, pode murmurar, numa aparente contradição: "Fechemos os olhos até que o sol comece a declinar. Até que a alma doce do Universo recomece a exalar-se do âmago das coisas" (MACHADO, 2002, pág. 61-62; grifos do autor).

É que ele está igualmente cônscio de outras determinações, que fazem o ciclo contínuo de dias e noites providencial: "Nada perder. Não se perder em nada. Mergulho, mas não residência no âmago das coisas. Tal o nadador que se deixa levar pelas águas: com a certeza de que pode vir à tona retomar respiração e repetir a aventura." (MACHADO, 2002, pág. 68; grifos do autor).

Para Aníbal, paira esperança para além de qualquer desespero, donde as reiteradas profissões de fé na vida. Então noite, para o mineiro, não é apenas o fenômeno temporal determinado pelo astro-rei e pelas rotações da terra. Com ou sem lua, uma luz própria caracteriza a noite, como demonstram, igualmente, trechos avulsos de Cadernos de João que não integram a "Topografia da insônia".

\section{O homem e a noite}

Não é à noite - dimensão poética ou conceito metafísico - que me refiro. Nem à noite moral, treva da alma, reminiscência teológica da ideia de queda ou pecado original. Mas à presença concreta, íntima, da noite: a que se aproxima da cama ou do banco de jardim para nos colher; a que nos dá de beber a sua substância de esquecimento; a que vem sem ser chamada e é esperada como um armistício. A noite necessária na qual nos enrolamos e se enrola em nós, noite particular e espessa com a qual dormimos.

Átomo da grande noite indivisível. (MACHADO, 2002, pág. 15)

Este texto, marcado pelas aliterações ("não é à noite"; "nem à noite"; "concreta, íntima, da noite"; "sua substância de esquecimento"; "a noite necessária na qual nos enrolamos"; "noite particular") e pelas rimas internas ${ }^{28}$ ("noite moral, treva da alma (...) pecado original"; "dimensão poética ou conceito metafísico", "para nos colher; a que nos dá de beber"; "a que vem sem ser chamada e é esperada como um armistício"), louva a noite como não só um evento, mas uma experiência singular dada a cada homem, universalmente, como um prêmio pela labuta diária, um cessar-fogo em meio aos combates, um acalanto que envolve e aconchega para o remanso necessário. Dosagem atômica da grande noite (a morte?) e que,

\footnotetext{
28 O uso da repetição de sons na forma de eco também é comum nos poemas em prosa: "O pássaro agonizante põe pela boca os milhares de quilômetros que devorou pelos ares" (MACHADO, 2002, pág. 9), em que "[a]ssim como o pássaro recolhe em si o espaço que percorreu, a palavra pássaro concentra na materialidade do signo o principal processo aliterativo do texto" (VICENTE, 2010, pág. 125); "que o teu canto, poeta, lançado ao mundo, sirva de fermento a preparar-Ihe a transformação e nunca de cimento a consolidarIhe os erros" (MACHADO, 2002, pág. 52); "Veio um vento de inverno, fiquei sem voz" (MACHADO, 2002, pág. 164). Ocorre também a reiteração rítmica: "Até o fim da vida... Mas que não seja a morte" (MACHADO, 2002, pág. 168; grifos do autor), com sentenças em hexassílabos, "Subiu a escada. A cama arrumada", com frases pentassílabas (MACHADO, 2002, pág. 87) ou "Rói as pedras como o vento, rói os ossos como um cão" (MACHADO, 2002, pág. 83; grifos do autor), redondilhas maiores intensificadas pela anáfora.
} 
portanto, concentra no mínimo a integralidade e a espessura do todo. Para essa noite benfazeja, convergem sentidos, a começar do título, que no par "o homem e a noite", ganha tonalidades eróticas.

“Quem já dormiu milhares de vezes, outras tantas pôde renascer" (MACHADO, 2002, pág. 124). A assimilação noite e morte, vigente desde pelo menos Antiguidade, quando sono e morte eram deuses irmãos, enfatiza aqui o despertar, em mais um compromisso com a claridade. Se voltamos à nossa dicotomia do princípio, no entanto, vida e obra estão um para o outro como sono e sonho. Nessa lógica, pode haver sono sem sonho (vida sem obra), sonho sem sono (quando o criador já não existe enquanto indivíduo ou quando se sonha acordado), sono com sonho (vida e obra se alimentando mutuamente)). Porém o sonho é, por si, estado intermediário entre vida e morte. Nesse caso, não é a vida que é sueño, mas a arte. E é a arte, não a vida, que é brevis. Todavia, se não nos falha a memória a equação não está completa sem o leitor. Mas aí temos sonho, vida, arte e sono de natureza distinta, e pouco tempo e espaço para tanto.

A noite serve para o sono, como garantia de indulto contra tudo o que foi desventura, falho, equívoco. Ela interrompe a continuidade entre aquele que errou ontem e o outro que acordará amanhã e faz jus a nova chance do alvorecer. O sono nivela os homens, tornando-os tão indefesos como inofensivos. A falta de sono, neste cenário, tanto pode ser prova cabal da nossa nulidade enquanto dirigentes da própria paz e sossego, frente a uma provocação externa, como da saudável alteração da percepção que a noite provoca: "Estava convencido, ao deitar-me, de que levava à cama um personagem de certa importância. Se me vissem agora! Se descobrissem a desmoralização que reina dentro de mim!" (MACHADO, 2002, pág. 118) A noite, desafiando a renunciar ao que se passa em redor pelo baixar das pálpebras, reclama ainda que nos dispamos das fantasias de grandeza: "Atiro fora os inimigos, os desejos, o orgulho, os escrúpulos, as imagens tristes, o excesso de roupas; tudo que pesa, atiro fora. Fecho os olhos como quem dá as costas ao mundo. Fico imóvel e finjo-me de morto, à espera de que o sono passe e me leve na Ambulância da Noite." (MACHADO, 2002, pág. 118)

\section{Considerações finais}

Um homem cuja morada se tornou porto, mineiro que morou no Rio, Aníbal Machado acumulou, retomando o Benjamin de "O narrador - considerações sobre a obra de Nikolai Leskov", o saber das terras distantes e o saber do passado (BENJAMIN, 1996, pág. 199), “aceita[ndo] o mundo sem se prender demasiadamente a ele" (pág. 200). Sua prosa tem a dimensão utilitária de que fala o filósofo, a habilidade de dar conselhos sem enfadar e uma impressão digital inigualável no panorama brasileiro: "Seu dom é contar sua vida; sua dignidade é contá-la inteira. (...) O narrador é a figura no qual o justo se encontra consigo mesmo" (pág. 221) No caso do escritor mineiro, o objetivo fundamental na escrita nunca foi a permanência, mas a transmissão. Assim, a luz tênue da narração não consumiu a mecha de sua vida, como pensou o pensador alemão; é a vida que ilumina a narração, infundindo nela calor e dando-lhe sobrevivência.

Procuramos, nesse recorte, pensar nele como homeopoeta. A tentativa, com a palavra esdrúxula (a bem dizer, paroxítona), é conjugar alguns sentidos: 1. A ideia de alguém que oscilou entre as personas de 
homem e de poeta, identificando-se ora com a vocação para a literatura, ora com a existência plena como cidadão, marido, pai; 2 . A noção de um poeta, tomando a palavra no sentido amplo, de doses homeopáticas, isto é, sobretudo de formas breves; 3. A concepção de criador que buscava principalmente os iguais, o indivíduo comum em sua nobreza e mediocridade essencial; 4. A compreensão de que, na condição de escritor e também na vida, a cura está em fugir do excesso e perseguir a justa medida, a conciliação dos contrários pela percepção do que existe de identidade e similitude; 5 . A proposição de artista que é solidário com o semelhante, não se colocando como superior, mas nivelando-se para ter eficácia; 6 . 0 desapego à arte como projeto absoluto, elegendo-a antes como meio de, pintalgando a experiência cotidiana, qualificar a vida e torná-la mais saborosa; 7. A convicção de que viver é uma arte como as outras, e bem viver é ser um mestre do ofício.

\section{Referências bibliográficas}

ALONSO, Rodolfo. Em torno a Aníbal Machado. Revista Travessia: Luís Delfino 150 anos 1834/1984. Florianópolis: UFSC, v. 5, n. 8/9 (1984).

ANDRADE, Carlos Drummond de. $O$ irmão de João Ternura. MINAS GERAIS. Suplemento Literário. Belo Horizonte, v. 10, n. 477, pág. 4, nov. 1975.

ANTELO, Raúl (org.). Parque de diversões Aníbal Machado. Belo Horizonte: UFMG; Florianópolis: UFSC, 1994.

BARBOSA, Manuela Ribeiro; CORNELSEN, Elcio Loureiro. K. no Brasil: Kafka, Murilo Rubião e Aníbal Machado. Belo Horizonte, Universidade Federal de Minas Gerais, 2014. (Tese de Doutorado)

BENJAMIN, Walter. O narrador - considerações sobre a obra de Nikolai Leskov. In: Magia e técnica, arte e política: escritos sobre literatura e história da cultura. Obras escolhidas, volume 1. Tradução de Sergio Paulo Rouanet. São Paulo: Brasiliense, 1987.

BOSI, Alfredo (org.). Situação e formas do conto brasileiro contemporâneo. In: 0 conto brasileiro contemporâneo. Seleção de textos, introdução e notas bibliográficas por Alfredo Bosi. São Paulo: Cultrix, 2006. pág. 7-22.

BRANDER, Myriam Lay. Íntimos Arquipélagos: La Aforística en Cadernos de João de Aníbal Machado y la Poética de la Archipelización. Revista Chilena de Literatura. Septiembre 2015, Número 90, pág. 129-150.

CAMPOS, Paulo Mendes. Aníbal Machado. MINAS GERAIS. Suplemento Literário. Belo Horizonte, v. 19, n. 905, pág. 3, fev. 1984.

CARPEAUX, Otto Maria. Presença de Aníbal. MINAS GERAIS. Suplemento Literário. Belo Horizonte, v. 19, n. 904, pág. 2, jan. 1984.

CARVALHO, Bernardo. O interminável livro da vida de Aníbal Machado. Folha de S. Paulo. Mais! São Paulo, domingo, 10 de julho de 1994. Disp. http://www1.folha.uol.com.br/fsp/1994/7/10/mais!/17.html. Acesso em 8 de maio de 2014.

CECHINEL, Francilene Maria Alves Ribeiro. O miniconto e a história da minificção brasileira. Tese de doutorado. Universidade Federal do Rio Grande (FURG), Instituto de Letras e Artes, 2019.

DIMAS, Antônio. Magia e ternura. In: Os melhores contos de Aníbal Machado. São Paulo: Global, 2001, pág. 5-12.

LACERDA, Andréa Maria de Araújo; LÚCIO, Ana Cristina Marinho Lúcio. 0 espaço ficcional em contos de Aníbal Machado. João Pessoa: Universidade Federal da Paraíba, 2013. (Tese de doutorado) 
MACHADO, Aníbal. A aparição dos sapatos. Revista Travessia: Luís Delfino 150 anos $1834 / 1984$. Florianópolis: UFSC, v. 5, n. 8/9 (1984).

MACHADO, Aníbal. Cadernos de João. Rio de Janeiro: Nova Fronteira, 2002.

MACHADO, Aníbal. A morte da porta-estandarte e outras histórias. Rio de Janeiro: José Olympio, 1974.

MACHADO, Aníbal. João Ternura. Rio de Janeiro: José Olympio, 2004.

MACHADO, Aníbal. A arte de viver e outras artes: Cadernos de João, ensaios, crítica dispersa e auto-retratos. Depoimento de Paulo Mendes Campos. Apresentação de Leandro Konder. Rio de Janeiro: Graphia Editorial, 1994.

MACHADO, Aníbal. Dois textos de Aníbal Machado. Revista Travessia: Modernismo. Florianópolis: UFSC, v. 3, n. 5 (1982).

MACHADO, Maria Clara. Aníbal Machado, meu pai. MINAS GERAIS. Suplemento Literário. Belo Horizonte, v. 19, n. 904, pág. 3, jan. 1984.

MACHADO FILHO, Aires da Mata. Aníbal Machado. MINAS GERAIS. Suplemento Literário. Belo Horizonte, v. 19, n. 904, pág. 1, jan. 1984.

MAGALHÃES, Carlos Augusto de. Encontros e confrontos com a urbe multifacetada - uma leitura do conto "O telegrama de Ataxerxes" de Aníbal Machado. Cerrados, 8(9), pág. 155-164, 1999. Disponível em https://periodicos.unb.br/index.php/cerrados/article/view/1006. Acesso em 7 mar. 2020.

MEYER, Augusto. Textos críticos. Organização de João Alexandre Barbosa. Perspectiva: São Paulo, 1986.

MINÉ, Elza. Um vigoroso agente da modernidade. MINAS GERAIS. Suplemento Literário, Belo Horizonte, v. 19, n. 904, pág. 11, jan. 1984.

NAVA, Pedro. Beira-mar. São Paulo: Ateliê; Giordano, 2003.

OLINTO, Antônio. Cadernos de Crítica. Rio de Janeiro: José Olympio, 1959.

PAES, José Paulo. O surrealismo na literatura brasileira. In PAES, José Paulo. Gregos e baianos: ensaios. São Paulo: Brasiliense, 1985.

PONTES, Mario. O iniciado do movimento. In: MACHADO, Aníbal. João Ternura. Rio de Janeiro: José Olympio, 2004, pág. 7-13.

PROENÇA, Manuel Cavalcanti. Os balões cativos. In: MACHADO, Aníbal. A morte da porta-estandarte e Tati, a garota e outras histórias. Rio de Janeiro, José Olympio, 1977, pág. xix-xxxviii.

TEIXEIRA, Marcos Vinícius. Sob a máscara de Antônio Verde: um estudo do universo literário de Aníbal Machado no início do século XX. O Eixo e a Roda, Belo Horizonte, v. 27, n. 2, pág. 265-281, 2018.

SUPLEMENTO LITERÁRIO. Aníbal Machado: João Ternura. MINAS GERAIS. Suplemento Literário. Belo Horizonte, v. 10, n. 477, p. 1, nov. 1975.

TEIXEIRA, Marcos Vinícius; BOECHAT, Maria Cecília Bruzzi. João Ternura: romance de uma vida. Minas Gerais: Universidade Federal de Minas Gerais, 2005. (Dissertação de mestrado)

TEIXEIRA, Marcos Vinícius; MOURA, Murilo Marcondes de. Aníbal Machado: um escritor em preparativos. São Paulo: Universidade de São Paulo, 2011. (Tese de doutorado)

TOKIMATSU, Rosana Fumie. O iniciado do movimento: a ficção de Aníbal Machado e o cinema. São Paulo, 2017. 145 pág. Tese (Teoria Literária e Literatura Comparada) - Faculdade de Filosofia, Letras e Ciências Humanas, Universidade de São Paulo.

VICENTE, Adalberto Luís. O fragmento poético em Cadernos de João, de Aníbal Machado. Revista Texto poético (Anpoll), vol. 9, 2o semestre de 2010. p. 118-126.

WEISZ, Helena. João Ternura: Um livro à revelia do próprio autor. Sinal de menos. Ano 2, n. 6, dezembro de 2010, pág. 131-145. 
WERNECK, Humberto (curador). Aníbal Machado: artista do verbo e da vida. Catálogo de exposição itinerante. Belo Horizonte: Secretaria de Cultura de Minas Gerais/ Superintendência de Bibliotecas Públicas de Minas Gerais, $2007 . \quad$ Disponível em: <http://www.cultura.mg.gov.br/arquivos/Bibliotecas/File/exposicoesitinerantes/artista-do-verbo-da-vidaanibal-machado.pdf>. Acesso em 10 de abril de 2014. 